\title{
Evolution of the Hoabinhian Techno-Complex of Tam Hang Rock Shelter in Northeastern Laos
}

\author{
Elise Patole-Edoumba1, Philippe Duringer ${ }^{2}$, Pascale Richardin ${ }^{3}$, Laura Shackelford ${ }^{4}$, \\ Anne-Marie Bacon ${ }^{5}$, Thongsa Sayavongkhamdy ${ }^{6}$, Jean-Luc Ponche ${ }^{7}$, Fabrice Demeter ${ }^{8}$ \\ ${ }^{1}$ Museum d'Histoire Naturelle de La Rochelle, La Rochelle, France \\ ${ }^{2}$ Université de Strasbourg (UDS), Ecole et Observatoire des Sciences de la Terre (EOST), Institut de Physique du \\ Globe de Strasbourg (IPGS), Centre National de la Recherche Scientifique (CNRS) Unité mixte de recherche \\ (UMR), Strasbourg, France \\ ${ }^{3}$ Centre de recherche et de restauration des musées de France (C2RMF), Palais du Louvre, Porte des Lions, \\ Paris, France \\ ${ }^{4}$ Department of Anthropology, University of Illinois at Urbana-Champaign, Urbana, USA \\ ${ }^{5}$ Centre National de la Recherche Scientifique (CNRS), Unité Propre de Recherche (UPR2147), Paris, France \\ ${ }^{6}$ Department of National Heritage, Ministry of Information and Culture, Vientiane, Laos \\ ${ }^{7}$ LMSPC, UMR7515 CNRS, Strasbourg, France \\ ${ }^{8}$ Départment Homme Nature Société (HNS), National Museum of Natural History, Unité Mixte de Recherche \\ (UMR7206), Paris, France \\ Email: elise.patole-edoumba@ville-larochelle.fr, duringer@unistra.fr, pascale.richardin@culture.gouv.fr, \\ Ilshacke@illinois.edu, anne-marie.bacon@cnrs.fr, thongsas@gmail.com, ponche@unistra.fr, \\ demeter@mnhn.fr
}

Received 14 July 2015; accepted 27 September 2015; published 30 September 2015

Copyright (C) 2015 by authors and Scientific Research Publishing Inc.

This work is licensed under the Creative Commons Attribution International License (CC BY).

http://creativecommons.org/licenses/by/4.0/

c) (i) Open Access

\section{Abstract}

Tam Hang rock shelter was excavated in 1934 by the French geologist Jacques Fromaget who discovered 13 skeletons and a lot of stone tools. But after the second War World, the lithic assemblages were lost. Then the site was forgotten since 2003, when the department of archaeology of the Lao Ministry of Culture relocated it and made with a French team a new prospection. In 2007 and after seven campaigns of excavations, a lot of archaeological materials had been found in two new areas opened at Tam Hang South and Tam Hang Central. More than 9000 specimens of stone have been found. This article proposes to give a new approach of the whole stratigraphy with C14 dating. It also makes a characterization of the lithic assemblage which belongs to the Hoabinhian techno-complex. 


\section{Keywords}

\section{Hoabinhian, Prehistory, Laos, Lithic Industry}

\section{Introduction}

The Human settlement in Laos has been studied since the late 19th century. Informal surveys conducted in Luang Prabang Province between 1879 and 1895 by the Pavie mission (e.g. Pavie, 1898-1919), and the pioneering excavations in Ban Don Tio cave (e.g. Mansuy, 1920) gave the first data for this archaeological terra incognita. Then an archaeological program undertaken by researchers of the Geological Service of Indochina was ambitious and in part successful for Laos (e.g. Colani, 1932, 1935; Fromaget, 1934, 1936, 1937a, 1937b, 1940a, 1940b, 1941, 1952; Saurin, 1935, 1966, 1968; Fromaget \& Saurin, 1936; Arambourg \& Fromaget, 1938).

After 60 years without excavations, archaeological investigations have increased in the northern part of Laos since the beginning of 2000s (e.g. Sayavongkhamdy et al., 2000; Raymaekers, 2001; Bacon et al., 2008, 2011, 2012; Demeter et al., 2010, 2012; White \& Bouasisengpaseuth, 2008; White et al., 2009; Zeitoun et al., 2012). Tam Hang rock shelter in Hua Pan Province was re-located at this occasion.

New archaeological investigations on the site were conducted by some of the authors during seven seasons between 2003 and 2013. They yielded rich cultural and faunal remains which provided new data about stratigraphy and human occupation and the environment (e.g. Demeter et al., 2010, 2012; Bacon et al., 2012). This paper proposes an assessment of stone industry chronology and Hoabinhian techno-complex sequence based on more than 9000 stone implements discovered on the site.

\section{Excavation}

Tam Hang rock shelter is located in the Annamitic Chain at an altitude of $1120 \mathrm{~m}$ in Hua Pan Province (see Figure 1). It is at the foothill of Pà Hang Mountain, 500 m eastward of Long Nguapha village. In 1934, Fromaget excavated three localities along the rock shelter wall, Tam Hang North (THN), Tam Hang Central (THC) and Tam Hang South (THS) for a total in length of $100 \mathrm{~m}$. In 2003 and then between 2007 and 2013, we extended the investigated surface in opening four new localities laterally behind the historical trench and the backfill excavation left by Fromaget to check stratigraphy and human occupation extension (see Figure 2).

\subsection{Stratigraphy and Radiocarbon Dating}

Because of the archeological campaign of Fromaget in 1934, most of the area in front of the cliff is covered by the remains of at least one year of excavation. These later can reach up to two meters in thickness according to place. They occur at the foot of the cliff on a ribbon of about $100 \mathrm{~m}$ length by $15 \mathrm{~m}$ width.

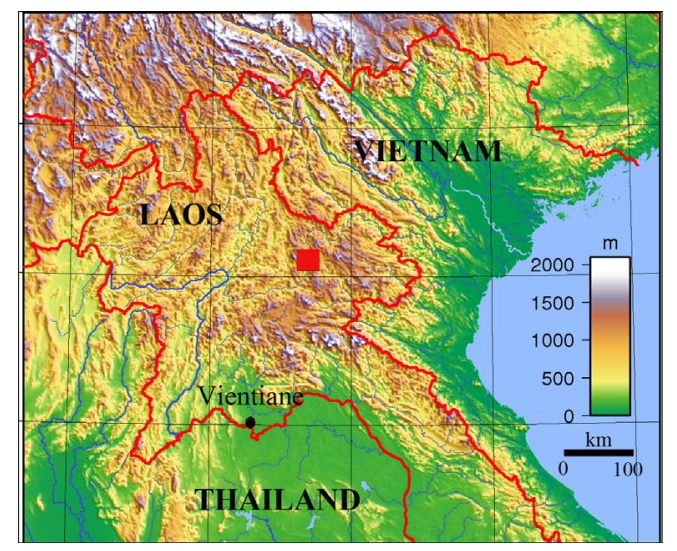

Figure 1. Location of Tam Hang rock shelter. 

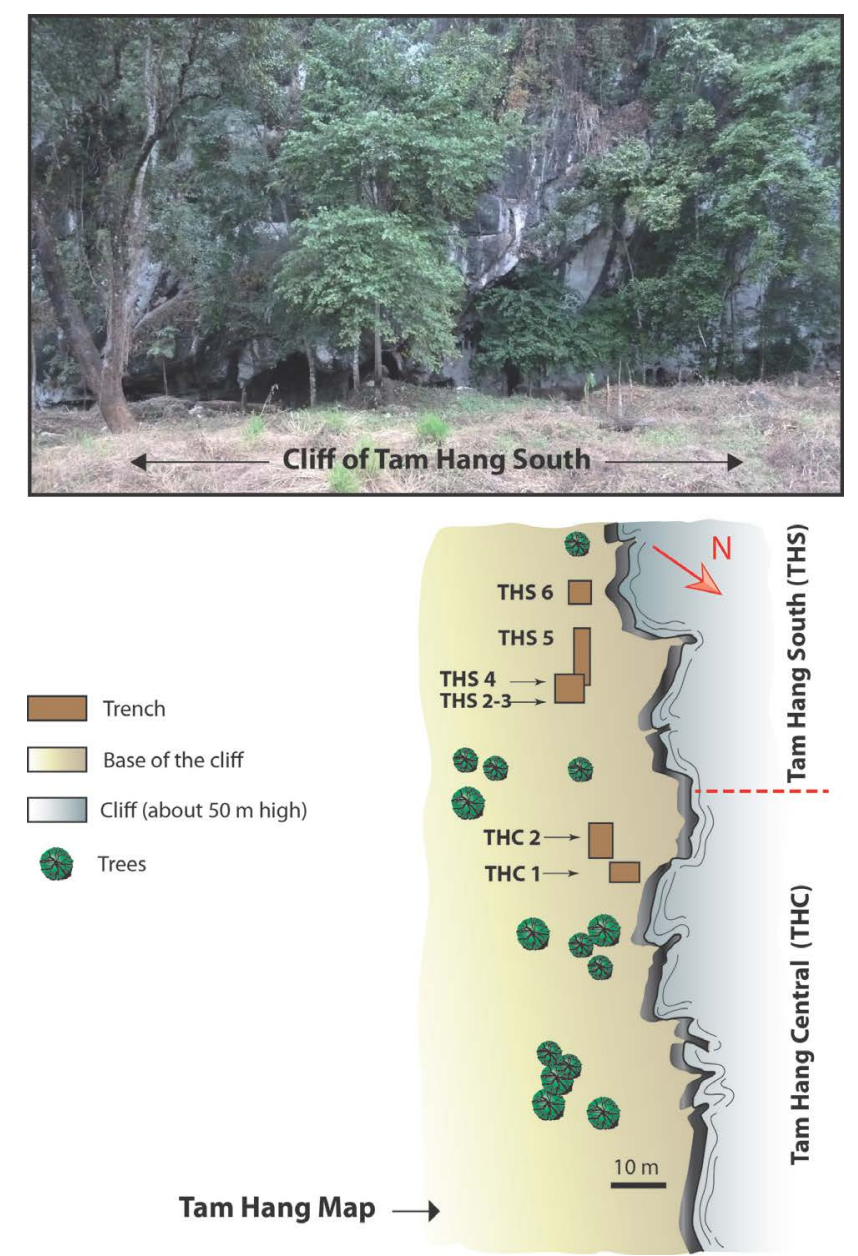

Figure 2. Location of different archaeological squares in Tam Hang South and Tam Hang Central (drawing: Ph. Duringer).

The sedimentary deposit from THS and THC are dominated by argillaceous sediments characterized by collapsed limestone block from the adjacent cliff (Moscovian to Permian limestone). Most of them are generally on size of boulder and block up to several meter length. Smaller clasts exist but are much less important except the anthropic tools. The sediment is wet and soft, mainly brown in color except the topmost part of the section strongly colored in dark due to the presence of the soil. Towards the base, the color is progressively changing to light brown and yellow. The clayey sediment is rich in sand and silt, sometimes enriched place to place by small limestone gravel, iron-oxide pisolite and small laterite clasts.

During 2003s' archaeological campaign, the stratigraphical and sedimentological contexts of THS were well identified (e.g. Demeter et al., 2010). A stratigraphical profile was recognized on ten meters depth with a conglomeratic upper part (until 5 meters depth) then clayish levels in the lower part (from 5 to ten meters). The master bedding displays a strong dip up to 45 degrees. This is the result of successive clast/sediment collapsing during long time from the nearby cliff. This high dip of the layer make that charcoal sampled from different depth can belong to the same layer. For example, samples dated at 13,251 and 11,625, separated vertically by 60 $\mathrm{cm}$ come in fact almost from the same layer separated only by $20 \mathrm{~cm}$. Most of the tools are coming from the same level (roughly between 3 and 4 meter from the surface). Levels higher and deeper have not delivered tools.

The section of THC is quite similar. It differs by a high concentration of tool between $1,5 \mathrm{~m}$ and $2,5 \mathrm{~m}$ and by horizontal master bedding. Charcoal samples gave six C14 calibrated dating between $9375 \pm 45$ BP and 9775 $\pm 35 \mathrm{BP}$. Bone and charcoal are scattered in both section from base to top. Thanks to this diachronic sequence, we studied this stone tool industry lithic as a possible evolution of technical skills over 5000 years correlated with the Late Pleistocene/Early Holocene transition (Figure 3 and Table 1). 


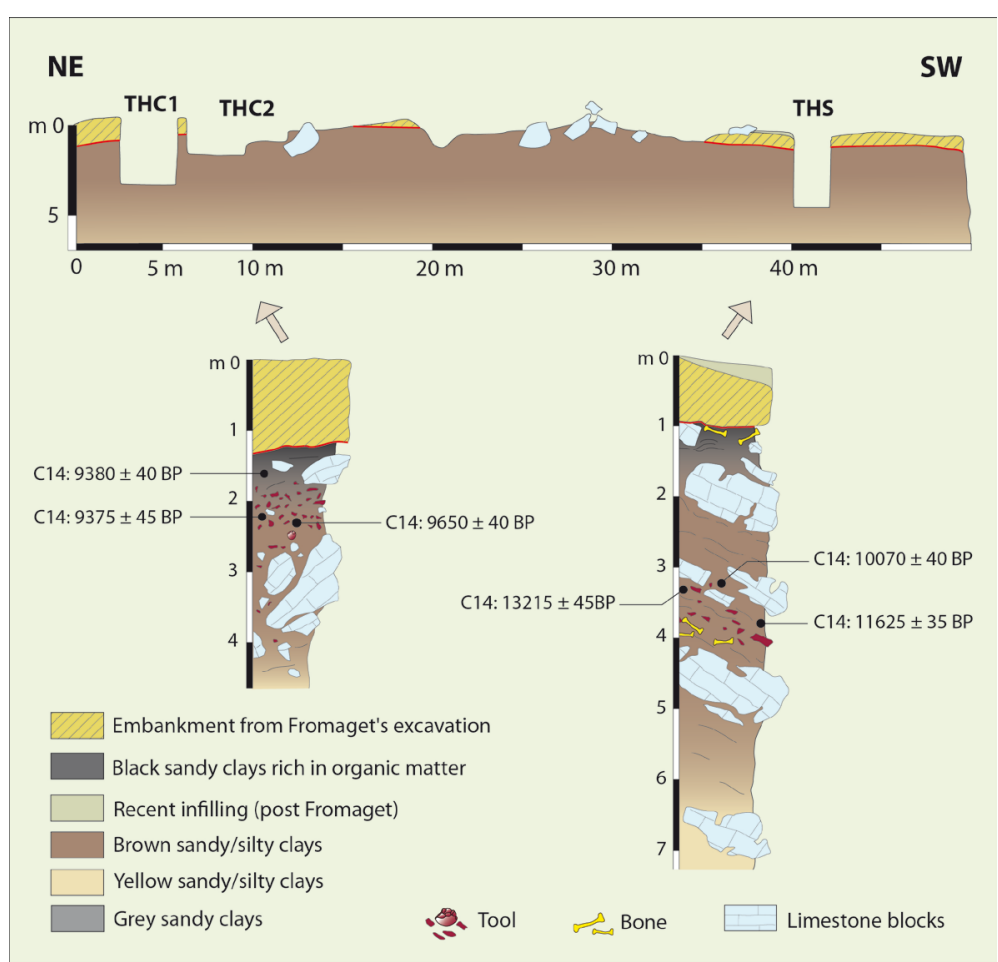

Figure 3. Stratigraphy of the squares excavated with $\mathrm{C} 14$ dating (drawing: $\mathrm{Ph}$. Duringer).

Table 1. C14 calibrated dating (BP) of different cultural layers in locus THS4, 5 and THC2. 'Radiocarbon Dating Laboratory, Illinois State Geological Survey, University of Illinois at Urbana-Champaign, USA. ${ }^{* *}$ Centre de Recherche et de Restauration des musées de France (C2RMF), France.

\begin{tabular}{cccc}
\hline Area & Depth & Lab. ref. & C14 age (yr BP) \\
\hline S4 & $-3.82 \mathrm{~m}$ & $\mathrm{~A} 1121$ & $11625 \pm 35^{*}$ \\
$\mathrm{~S} 5$ & $-3.13 \mathrm{~m}$ & $\mathrm{~A} 1293$ & $10070 \pm 40^{*}$ \\
$\mathrm{~S} 5$ & $-3.25 \mathrm{~m}$ & $\mathrm{~A} 1135$ & $13215 \pm 45^{*}$ \\
$\mathrm{C} 2$ & $-1.62 \mathrm{~m}$ & $\mathrm{~A} 1292$ & $9380 \pm 40$ \\
& & $\mathrm{~A} 1224$ & $9775 \pm 35^{*}$ \\
$\mathrm{C} 2$ & $-2.24 \mathrm{~m}$ & SacA 29965 SacA 29966 & $9375 \pm 45^{* *}$ \\
& & & $9505 \pm 40$ \\
$\mathrm{C} 2$ & $-2.26 \mathrm{~m}$ & SacA 29967 SacA 29968 & $9650 \pm 40^{* *}$ \\
\end{tabular}

\subsection{Method: Stone Artifact Analysis}

Lithic assemblages found in THC and THS are relatively homogeneous with tools, flakes, hammers and raw materials. Results are based on techno-functional analysis of all stone artefacts (e.g. Lepot, 1993; Boëda, 1997, 2001; Bourguignon, 1997; Soriano, 2001). In this analysis, the typological approach is associated with a functional framework which can decode the behavioural information encapsulated in products. We have focused on the significance of the attributes of all the products of stone working (flakes, tools, and cores) to therefore reconstruct the processes by which stone tools were made, thanks to diacritical reading of each tool and in conjoining stone tools ("remontage"). Macroscopic features of converted edges were also identified.

\section{Results for Tam Hang South}

The re-investigations initiated in 2003 were conducted in the southern area in locus 2, 3, 4, 5 and 6. Excavations 
delivered more than 900 knapped stones mainly located in locus 4 and 5 in levels dated between 10,070 $\pm 40 \mathrm{BP}$ and $13,215 \pm 45 \mathrm{BP}$.

The corpus analysis throughout the stratigraphy shows a change in the assemblage composition (see Table 2). In the upper-levels, cores and flaked tools are more abundant than in lower levels, and core tools that characterize deeper levels are less abundant. It's the same with the increase of raw materials and flakes $(74 \%$ to $90 \%)$ that can be explained by the evolution of the flaking process which will be discussed later..

\section{Tool Types}

Core tools and flaked tools coexist in the same layers. Flaked tools have either re-sharpened edges or were used directly. This sample represents over $9 \%$ of the whole corpus.

Three types of core tools were recovered throughout the sequence: sumatralith, massive scraper-like tools and blocks which include a variety of worked pebbles or cobbles with a cortical preserved surface. Whatever the type of core tool, the size of raw material (pebbles or cobbles) is quite similar.

Sumatralith are cobbles flaked on one side (Figure 4). Two to three generations of flake removals are initiated from the opposite cortical surface. They produce a specific tool shape (sub-triangular, flounder, oval, circular or oblong associated to two kinds of cross-sections: plano-convex or biconvex) with a peripheral edge of which some portions are used. Each tool has at least three active parts with angles ranging from $40^{\circ}$ to $85^{\circ}$ with an average between $60^{\circ}$ and $70^{\circ}$.

The assemblage also has half-sumatralith which belongs to the short-axe type defined by Colani (e.g. Colani, 1929b; Mattews, 1966). We noticed that all the short-axes of this assemblage got from sumtralithes. Once the manufacture tool is completed, the stone artefact is struck. A transverse fracture is visible at one end of the sumatralith. This technical process may have been used to get a specific size and shape. The half-sumatralith has the same shape and volume as the other unfractured specimens (Figure 5). Whole specimens probably would have been too bulky or heavy for Prehistoric men.

Massive scrapers of the assemblage are made from quadrangular pebbles or a cobble fragment of which a straight or convex natural edge is sharpened (Figure 6). They have the same size and weight as the sumatralithes. The flaking strategy also seems similar. The knapper sharpened the forehead formed by the intersection of the cortical surface and the flaked surface.

Backed scraper-planes were also identified in various areas. They look like scrapers but the sharpened edge presents large flat removals.

The bifacial specimens are particularly scarce. Two shaped tools show bipolar and incomplete removals opening opposite sharp-cutting edges.

$4 \%$ of the tools corpus are flakes. This category includes flakes with macro-use wears and retouched edges. Eight different types have been identified: scraper, notch, denticulate, end-scraper, burin, drill, scraper and denticulate, scraper-notch and used flakes.

Blank selection appears to be based on size (see Table 3). Tools are systematically longer and thicker than debris. Their size also changes over time. In the deeper levels, they are bigger and thicker than the upper levels. Their selection takes place at the beginning of the operating process.

Table 2. Assemblages composition in the different layers.

\begin{tabular}{|c|c|c|c|c|c|c|c|c|}
\hline \multirow{2}{*}{ Type } & \multicolumn{2}{|c|}{ Upper level (undated) } & \multicolumn{2}{|c|}{ Before $10,000{ }^{14} \mathrm{C}$ yr } & \multicolumn{2}{|c|}{ Between 10,000 and $11,500{ }^{14} \mathrm{C}$ yr } & \multicolumn{2}{|c|}{ After $11,500{ }^{14} \mathrm{C}$ yr } \\
\hline & Number & $\%$ & Number & $\%$ & Number & $\%$ & Number & $\%$ \\
\hline Raw material & 37 & 21.1 & 177 & 56.6 & 67 & 39.9 & 127 & 47.2 \\
\hline Flakes & 93 & 52.9 & 117 & 37.4 & 70 & 41.7 & 128 & 47.6 \\
\hline Core tool & 3 & 1.7 & 18 & 5.7 & 21 & 12.5 & 8 & 3 \\
\hline Flaked tool & 23 & 13 & 0 & 0 & 10 & 5.9 & 4 & 1.5 \\
\hline Core & 18 & 10.2 & 1 & 0.3 & 0 & 0 & 0 & 0 \\
\hline Hammerstone & 2 & 1.1 & 0 & 0 & 0 & 0 & 0 & 0 \\
\hline Undetermined & 0 & 0 & 0 & 0 & 0 & 0 & 2 & 0.7 \\
\hline Total & 176 & 100 & 313 & 100 & 168 & 100 & 269 & 100 \\
\hline
\end{tabular}




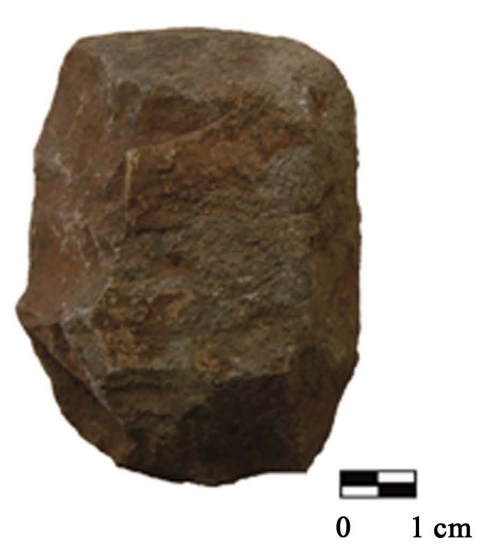

2007-THS4-21-1

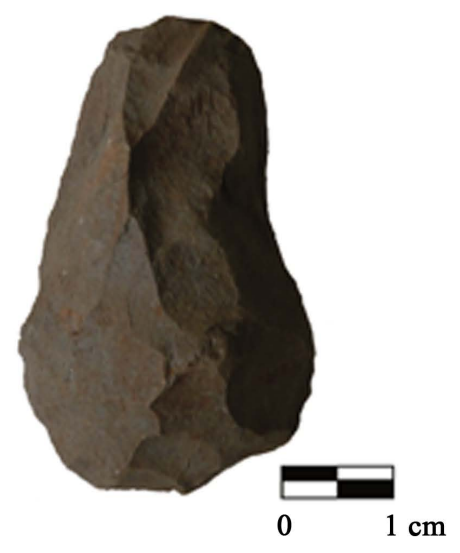

2007-THS5-3-1

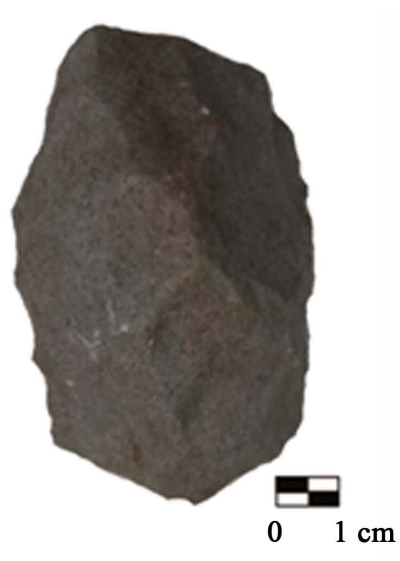

2008-THS5-131 bis

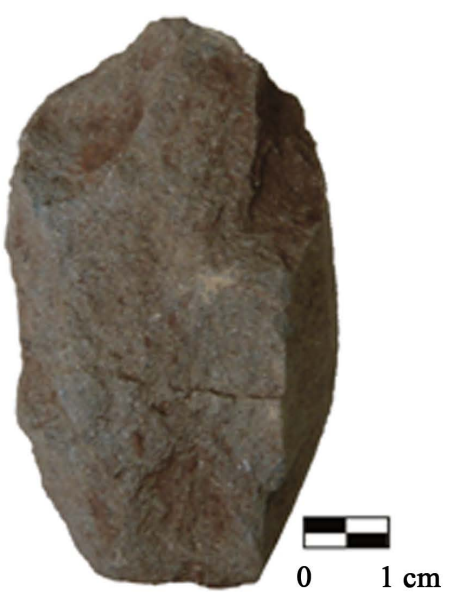

2007-THS5-6-1

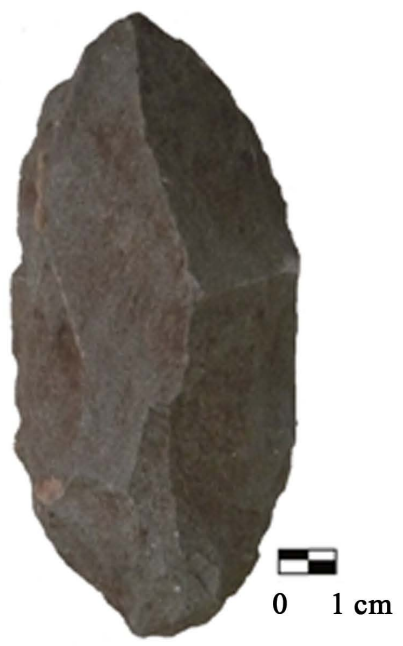

2008-THS5-157

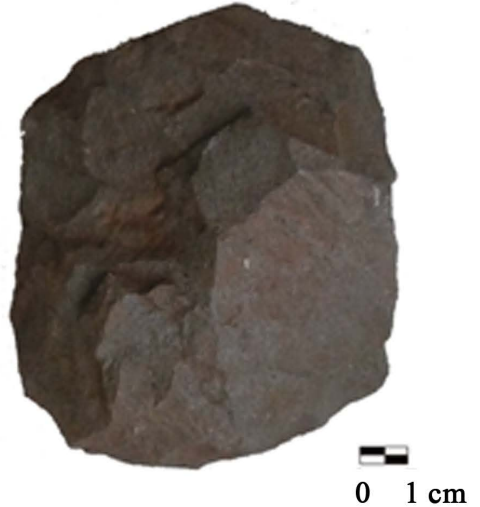

2007-THS4-29-1

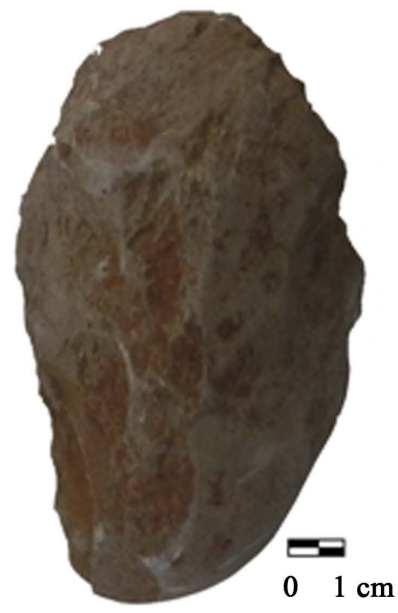

2008-THS5-132

Figure 4. Sumatralithes (photo: E. Patole-Edoumba). 


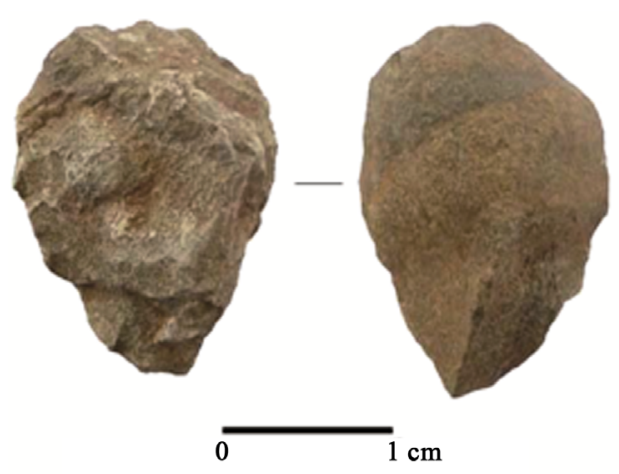

1) 2010-THC-56.1

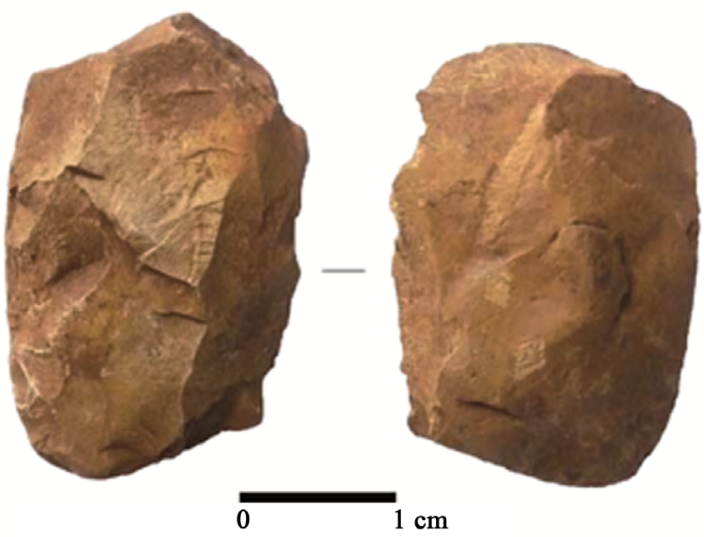

3) 2010-THC-10.1

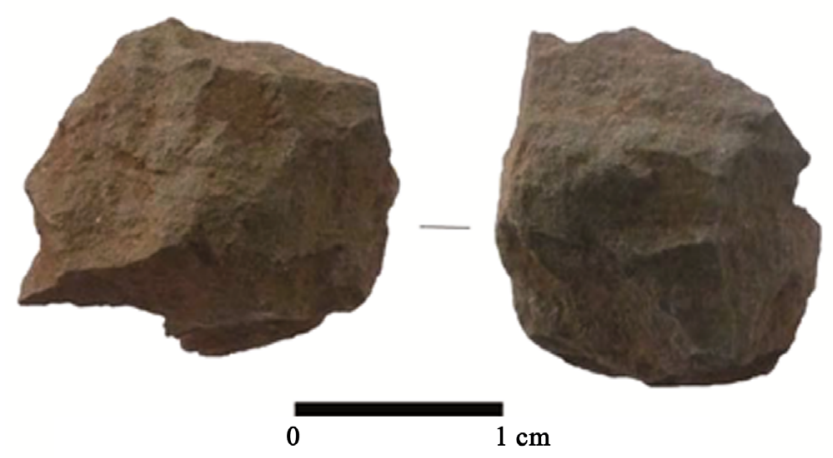

5) 2010-THC-14.1

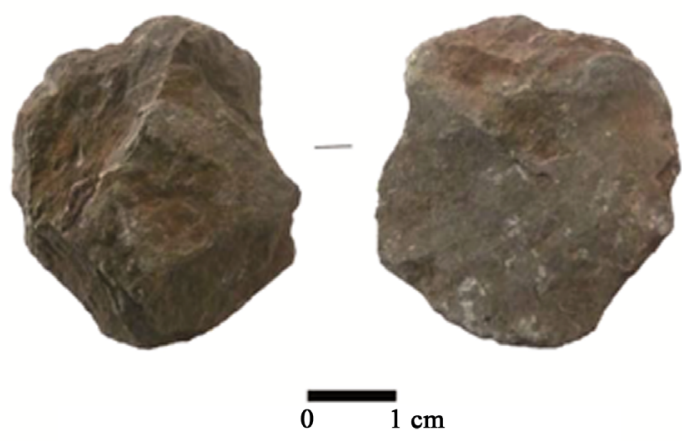

2) 2010-THC-19.1

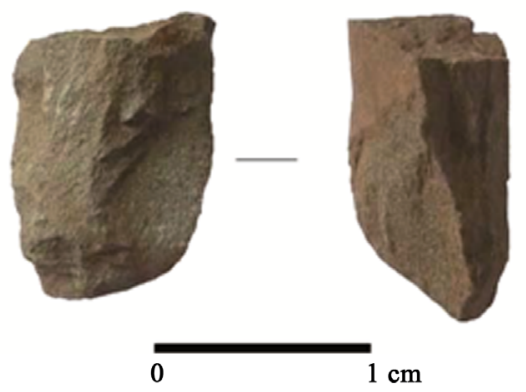

4) $2010-$ THC-1.1

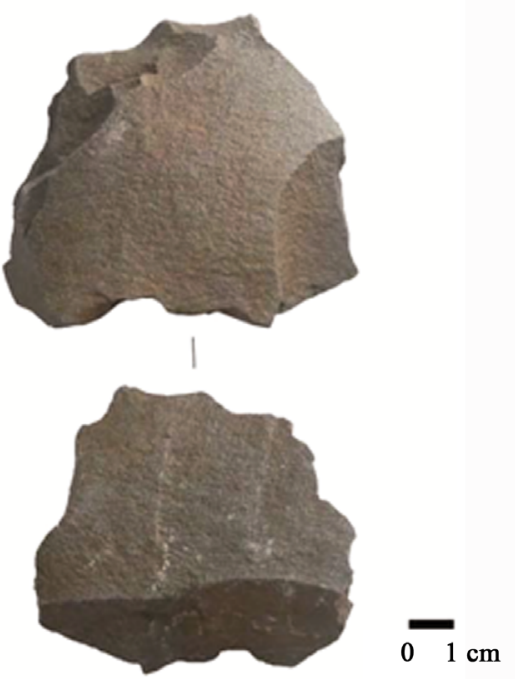

6) 2010-THC-50.1

1, 2, 3: Sumatralithes; 4, 5, 6: Half-sumatralithes

Figure 5. Sumatralithes $(1,2,3)$ and half-sumatralithes $(4,5,6)$ (photo: E. Patole-Edoumba). 


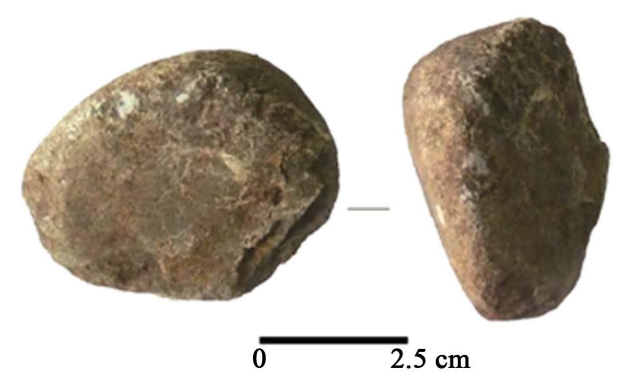

1) 2010-THC-141

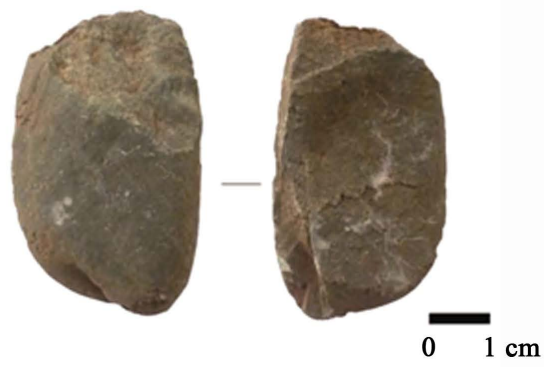

2) 2010-THC-17.1
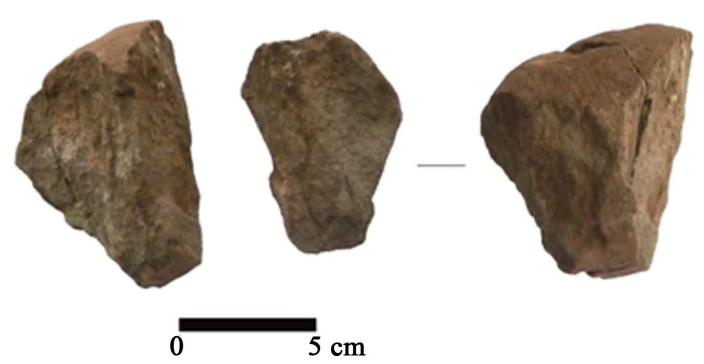

3) 2010-THC-16.1 et 2

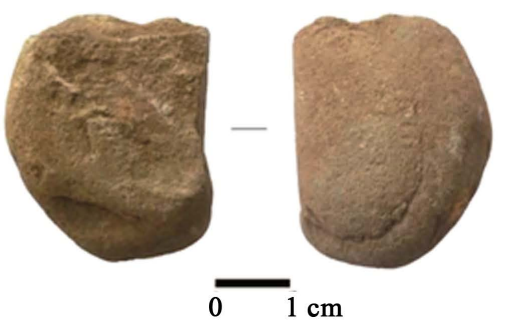

4) $2010-\mathrm{THC}-35.1$

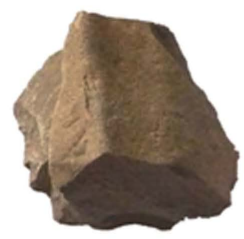

$5 \mathrm{~cm}$

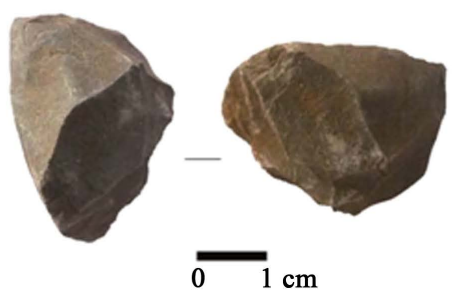

5) 2010-THC-21.2: racloir massif

6) 2010-THC-21.3: racloir massif

1, 2, 3, 4: Choppers, chopping tool; 5 and 6: scrapers

Figure 6. Choppers, chopping tools ( 1 to 4 ) and scrapers (5 and 6) (photo: E. Patole-Edoumba).

Table 3. Average size of flakes and tools of different levels.

\begin{tabular}{ccc}
\hline & Flakes & Tools \\
\hline Length $(\mathrm{cm})$ & 3.5 & 5.3 \\
Deviation & 2.7 & 1.7 \\
Width (cm) & 3.2 & 4.8 \\
Deviation & 1.4 & 1.5 \\
Thickness (cm) & 0.7 & 1.6 \\
Deviation & 0.4 & 0.5 \\
\hline
\end{tabular}




\section{Results of Central Area}

In the THC area, lithic assemblage belongs to a layer dated between 9300 and 9700 BP (see Table 1). More than 8000 artifacts were identified such as hammer and anvil, raw materials, choppers, sumatraliths, debris, retouched and used flakes. All these implements were connected with fragments of animal bones, sometimes burnt, assigned to Macaca cf. fascicularis, Arctonyx collaris cf. rostratus, Sus scrofa, Sus cf. scrofa, Bos frontalis, Bos cf. frontalis, Bos sauveli, Bos cf. sauveli, Bos javanicus, Bos cf. javanicus, cf. Bubalus bubalis, Cervinae indet., Axis porcinus, Cervus cf. unicolor, Rhinocerotidae indet., Rhinoceros cf. Unicornis.

\section{Tool-types}

Typology of tools is quite similar to those presented in Tam Hang South area with core-tools and retouched and used flakes produced during the reduction sequence.

In this area, the assemblage contains only $3.4 \%$ of core-tools. Six different types have been identified: sumatralithes, half-sumatralithes (36\%) and massive scrapers $(34.3 \%)$. The presence of half-sumatralithes is specific to this assemblage. During the flaking process, some pebbles are left when an edge is not convex enough to be sharpened in sharp-cutting $(21.2 \%)$. Some pebble fragments are also used without modification because a natural sharp-cutting exists $(0.9 \%)$. Three hemi-pebbles have been identified in this assemblage. This specific tool was identified in Thailand (Forestier et al., 2005). Their flaking involves a reduction sequence and a debitage method we will discuss later.

The size of all these tools is quite similar, between 9.2 and $8.6 \mathrm{~cm}$ long, 7.2 and $7.5 \mathrm{~cm}$ wide and 3.8 and 4.2 $\mathrm{cm}$ thick. During the reduction sequence, the initial volume of the raw material is reduced by at least $46 \%$ which explains the $73.6 \%$ of flakes of the assemblage. The strategy is more to decrease the pebble length (with a loss of $29.7 \%)$ and thickness $(17.6 \%$ on average) than to decrease the width $(6.6 \%)$.

One of the core-tool features is the production of one to three active or passive techno-functional units used for cutting, chopping or drilling on active way or for fitting or gripping.

Their size and angle are quite similar on these two types of tools with $5 \mathrm{~cm}$ in length and angles between $45^{\circ}$ and $85^{\circ}$.

Tools on flakes represent $1 \%$ of the assemblage. Six tool-types have been identified: notches, denticulated, scrapers, scraper with notch or scraper with denticulated, drill, used blanks (see Figure 7). Tools are longer, wider and thicker than debris (see Table 4). It was also performed in most cases during the first stages of the knapping process.

\section{Discussion: Knapping Techniques Changing over Time}

The typological analysis shows that stone tools have changed over time. Core tools dated from 11,500 BP are longer than the previous ones: length/width ratio is higher than before (1.6 compared to 1.1 and 1.2). Since 11,500 to $9300 \mathrm{BP}$ the sumatralith size decreases in relation to their weight ( $450 \mathrm{~g}$ to $120 \mathrm{~g}$ ) (see Table 5). This variability depends on the raw material selection process. Choppers were first favoured in the lower levels. They were much bigger around 13,000 BP then thinner around 9300 BP. During the Holocene, this kind of tool was substituted by tools on flakes whose size decreased throughout time. And there is less tool diversity in the undated upper level with four tool-types including burins, drills and end-scrapers previously missing.

The technical approach based on the identification of the knapping process gives us some explanation. We can also suggest that the climatic change between the Late Pleistocene and Early Holocene has been an impact on hunter-gatherer technical behavior.

\subsection{Raw Material Selection}

In 1934, Jacques Fromaget identified quartzites and schists. 99\% of the new assemblage is quartz sandstone and quartzite. Nevertheless, ryolites, trachytes, jasper type and some diorite were also used by Prehistorics. Different kinds of quartzite, well-cemented or not were present on the site. $20 \%$ of raw material picked up, was not useful because of its very bad quality. However, knappers focused on raw materials with the highest knapping-potential. Tools were made in fine quartzite and siliceous sedimentary and volcanic rocks which insure a good percussion wave.

Raw material origin is mainly local. The stream flowing at the bottom of the rock shelter may have been used to get pebbles as well as fragments of quartzite, and basalt. Milky quartz veins in the granitic series, which forms the bedrock of limestone and arkosic sedimentary series are common in the area and may have been a second choice. Raw materials have been stored on the site. Many fragments, sometimes with cortex, were found 


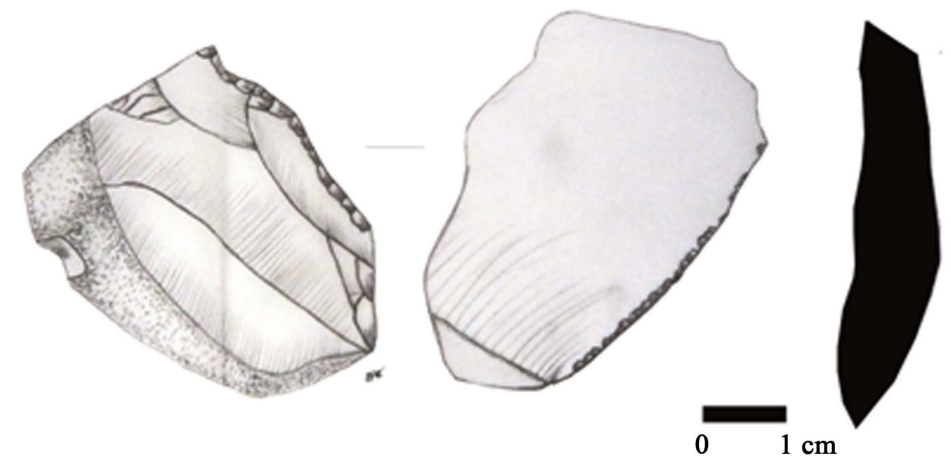

2009-THC-153 scraper
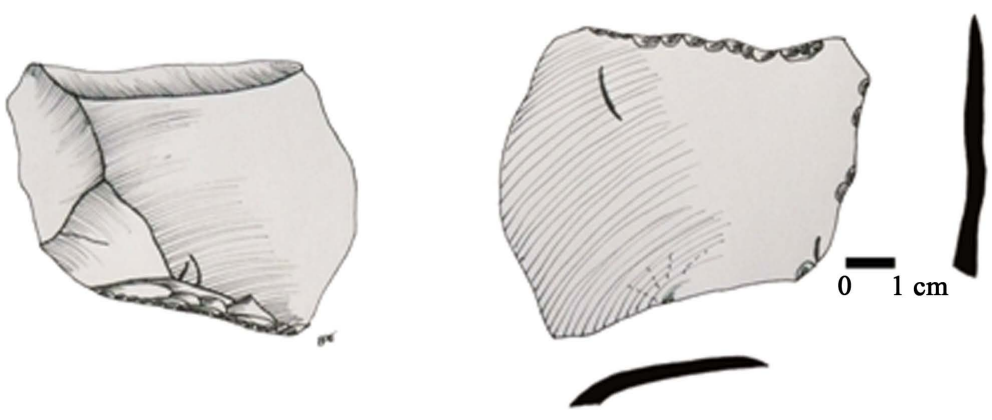

2009-THC-44-1 transverse scraper

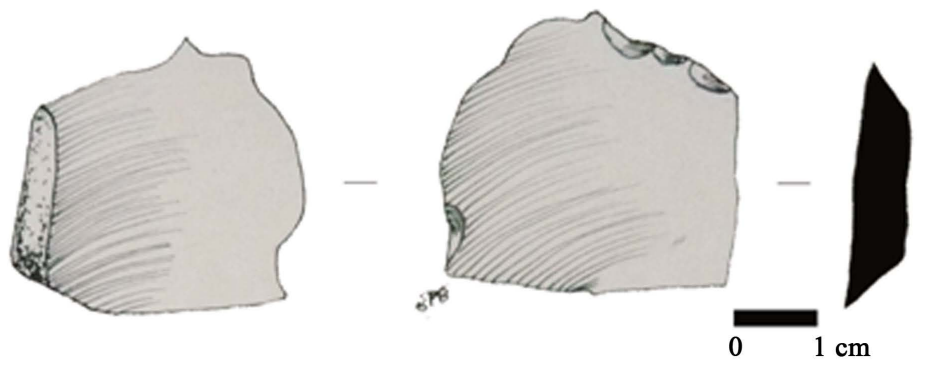

2009-THC-2 notch
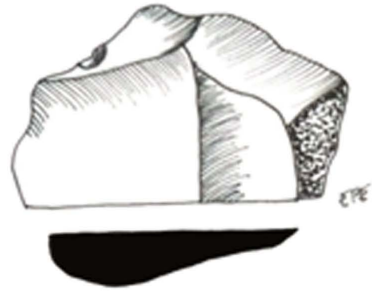
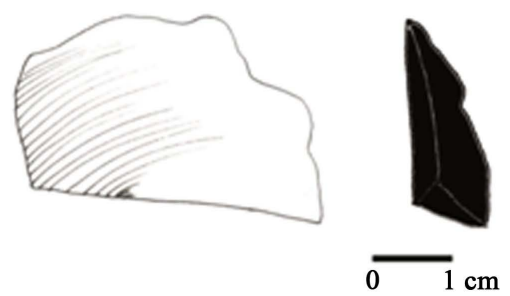

2009-THC-83 notch

Figure 7. Retouched flakes from Tham Hang Central (drawing: E. Patole-Edoumba). 
Table 4. Comparison of the average size of flakes (tools and debris).

\begin{tabular}{ccc}
\hline & Debris size $(\mathrm{cm})$ & Tools on flakes (cm) \\
\hline Length & 4.1 & 5.2 \\
Deviation & 2.1 & 1.8 \\
Width & 3.8 & 4.7 \\
Deviation & 1.5 & 1.6 \\
Thickness & 1.1 & 1.6 \\
Deviation & 0.5 & 0.7 \\
\hline
\end{tabular}

Table 5. Evolution of sumatralith in different layers.

\begin{tabular}{cccc}
\hline & Circa $9300{ }^{14} \mathrm{C}$ yr & Between 10,000 and $11,500{ }^{14} \mathrm{C} \mathrm{yr}$ & After $11,500{ }^{14} \mathrm{C} \mathrm{yr}$ \\
\hline Length $(\mathrm{cm})$ & 9 & 9.5 & 11.4 \\
Deviation & 2.8 & 1.5 & 0.6 \\
Width (cm) & 7.3 & 7.6 & 7 \\
Deviation & 1.4 & 2.3 & 0.4 \\
Thickness (cm) & 3.2 & 3.8 & 4 \\
Deviation & 0.5 & 0.6 & 0 \\
\hline
\end{tabular}

in different levels. In addition, we have conjoined flakes and cores until the original raw material was obtained. So we think the whole knapping process was realized in situ.

\subsection{Direct Percussion on an Anvil}

A slab of stone connected with a small hammerstone in Tam Hang Central, scars recognized on both ends of tools and wasted flakes allow us to think that a direct percussion with anvil and hammerstone was used. The core was rested on the anvil and braced by one hand while the other hand struck it with the hammerstone. Such a technique is well-known and useful for flaking spherical pebbles or without cortical dihedral, as well as rectangular cobbles (like the raw material available on the site). But the traditional technique of freehand direct hard-hammer percussion was also used at the end of the core reduction process.

\subsection{Functional Hypotheses}

The issue of tool uses in Palaeolithic Southeast Asia has been discussed for several years. Initial assumptions were made in the 1970's. Woodworking and bamboo butcher or activity has been proposed (e.g. Solheim, 1970; Hutterer, 1976, 1977; Sørensen, 1982; Reed, 1997; White \& Gorman, 2004). Usewears analysis has since confirmed these suggestions (e.g. Pookajorn, 1996; Higham \& Thosarat, 2004). It is also admitted that stone use was not exclusive in a tropical environment and as with current groups; prehistoric societies may have developed a kinetic technology based on wooden and bamboo material (e.g. Gourou, 1948; Dennell, 2009; Schick \& Zhuan, 1993; Solheim, 1970).

At Tam Hang rock shelter as at other Hoabinhian sites excavated in Vietnam and Thailand, invertebrates and vegetal remains are missing in archaeological layers (e.g. Gorman, 1971; Viet, 2004). However, on this site both sectors have delivered many burnt bone fragments of mammals (terrestrial and arboreal living in forested areas or in the surrounding plains) directly in association with lithic implements, suggesting a butchering activity on this place.

Furthermore, fauna currently hunted in these areas with throwing weapons (spears, arrows or darts) let us think that massive and heavy tools fitted on shafts would not have been efficient for this kind of activity. On the other hand, wood and bamboo scraping or cutting with different stone tools have been tested. And choppers, scrapers, sumatralithes and flakes seem suitable for transforming organic raw material (e.g. West \& Louys, 2007; Yosef et al., 2012, Pawlik, 2015). Both, arguments for a predation activity of forest mammals and an exploitation of vegetation in Tam Hang is likely, especially if we take into consideration the climatic change of the Pleistocene/ Holocene transition. Paleoclimatic studies in the Peninsula (e.g. Penny, 2001; Maxwell, 2001; Penny, 2006; Maxwell, 2004; Marwick \& Gagan, 2011; Cook \& Jones, 2012) show the appearance of the monsoon phenomena 
and the expansion of tropical forest during this period. It may explain the adaptive strategy of hunter-gatherers in sharpening smaller flaked tools at Tam Hang.

\subsection{Different Technical Systems in Upper and Lower Levels}

In undated upper levels in Tham Hang South, two different technical systems were identified: core reduction and debitage. Freehand direct hard-hammer percussion was used for debitage. Hammerstones found in layers are rounded waterworn sandstone pebbles of 80 to $120 \mathrm{~g}$ in weight. The core study recognized the same operating sequence based on the surface exploitation of the core. This method belongs to the algorithmic type system of alternating debitage surface (SSDA) during which, each sequence the previous debitage surface is used as a striking platform for new removals (e.g. Patole-Edoumba, 2012). The operating sequence is short with one to six removals. Most of the time, from one striking platform, blanks are flaked on one or two debitage surfaces. Hence sometimes bipolar flaking is realized on a same surface.

A core reduction method was also identified on a scraper-like core, a chopper and a sumatralith with partial removals on both sides. Such a tool is a variant of sumatralith-type. Both removals on the usually cortical surface are used to create a flat surface needed to develop a sharp edge.

The systematic technical study of core-tools found in lower levels highlights the predominance of a unifacial core reduction method from elongated flat pebble or rectangular pebble. The knapper skill is to use natural convexity of raw material block either to generate sharp edge and get massive scrapers or to develop a plano-convex volume (flat surface still remaining cortical) and releasing a potential active edge all around the tool. In this latter case, the flat or bi-plane cortical surface is predetermining for the development of the pre-determined convex surface. The butt flakes in "bird wings" shape point to the exploitation of natural convexities.

In the first case, the operating system is quite short (two to three generations of removals on one edge). In the second, we see various stages from shelling to sharpening. Sometimes as a result of this process, sumatralith is half-broken in thickness to reduce its size. This operating sequence generates many flakes $(70 \%$ of the whole assemblage), a single tool can require up to 30 removals. So, for 222 core-tools, over 4000 flakes were discarded. Bifacial tools from the assemblage result from the same process (see Figure 8).

This option is considered when the edge created by the natural surface and the flaked surface is not suitable or sharp enough. Prehistoric man changes it by removals on the cortical surface. Sometimes, the plano-convex volume expected is not achieved despite the convexities depletion. In this condition, it's a bifacial tool with a triangular or trapezoidal cross-section which is sharpened.

Also, we suggest that some tools are stages in a same operating sequence whose purpose is to get a suitable edge (convex or straight closed to the average of $70^{\circ}-75^{\circ}$ with a somewhat concave cutting). The first stage is to generate a single edge (chopper, massive scraper, notched or serrated) which can become half-peripheral or on the entire circumference such as sumatralith (artefact with the most successful volume) that allows it to generate several edges. We even suggest the sumatralith is the culmination of a chopper-chopping tool in so far as it proposes an optimization of the potential of a sharp edge peripheral. In this scheme, the bifacial tool appears to be a result of the knapper inability to shape the specific volume of sumatralith.

A system variant has been identified on three artifacts that are hemi-pebbles. Their production involves a process scheme with debitage then core reduction. Raw material is flaked in two parts lengthways using a bipolar flaking on an anvil. Edges of each hemi-pebble are then sharpened with removals and retouches (see Figure 9). These removals are on the flaking surface preserving the cortical surface. During this process, the knapper makes a selection of flakes from the first or second generation of removals to convert them into tools.

\section{Conclusion}

Tam Hang assemblage belongs to the regional Hoabinhian facies discovered during the 1920's and 1930's by Madeleine Colani in Vietnam and reassessed several times since this period (e.g. Colani, 1929a, 1929b; Saurin, 1951; Heekeren, 1961; Mattews, 1966; Boriskovsky, 1969; Hayden, 1977; Schoocongdej, 1996; Hoang, 1989; Pookajorn, 1990; Bellwood 1997; Forestier 2005; Yi et al., 2008, Marwick, 2008, 2013, Forestier et al., 2010). Different meanings were given to Hoabinhian such as a culture, an industry, a chronological sequence, a tradition or a techno-complex since its first characterisation at the Préhistoric Congress of Far East in 1932 (Moser, 2001, 2012).

We retain the concept of a techno-complex based on: i) a lithic assemblage including tool types of Sumatralith, short-axe, disc and "the amorphous tool types" such as scraper, chopper, flakes (Gorman, 1972; Pookajorn, 1990; 


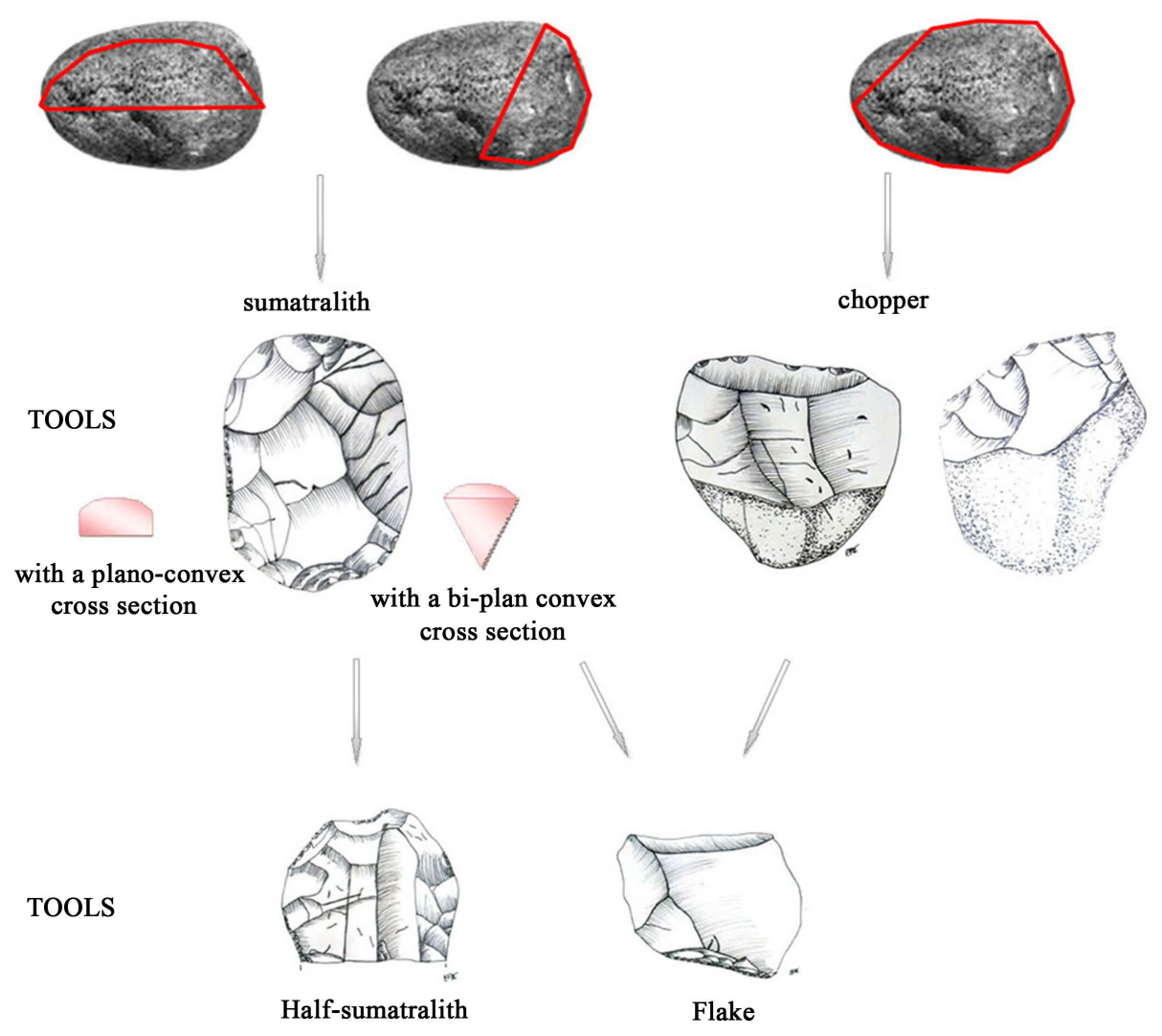

Figure 8. Core reduction process (drawing: E. Patole-Edoumba).

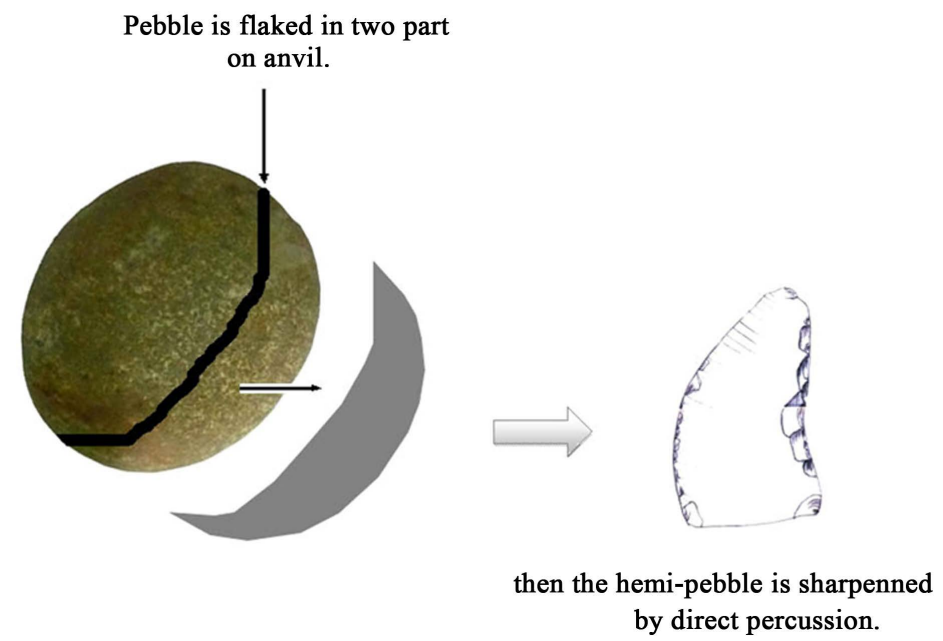

Figure 9. Operating process with debitage and core reduction (photo and drawing: E. PatoleEdoumba).

White \& Gorman, 2004); ii) three specific operation sequences concerning cobble tools (Zeitoun et al., 2008; Patole-Edoumba, 2012; Forestier et al., 2013; Forestier et al., 2015); iii) a specific paleoenvironment context (Gorman, 1972).

Identified in more than 150 sites in Southeast Asia, this facies, appearing during just before the Last Glacial Maximum (LGM) circa 30,000 years BP in Vietnam, Thailand and Burma (e.g. Aung, 1969; Sørensen, 1982; Santoni et al., 1990; Binh, 1991; Bowdler, 2008; Yi, et al. 2008; Marwick, 2008, 2013), had extended to India and Australia and might be the Philippines (e.g. Solheim, 1974; Sharma, 1988; Moser, 2001, Hazarika, 2012, 2013; 
Gaillard et al., 2011, Soni et al., 2014), and it continued until 10,000 years BP and 3000 years BP particularly in Malaysia (e.g. Dunn, 1964; Mattews, 1966; Gorman, 1971; Glover, 1977; Bellwood, 1993, 1997; White \& Gorman, 2004; Forestier et al., 2013; Higham, 2014). Dating and cultural implements in Tam Hang correspond to second stage or classical Hoabinhian (18,000-10,000 years BP) defined by Madeleine Colani for Vietnamese sites. Therefore, the rock shelter is one of the first cultural markers for Laos as sites in Khan and Pa Valleys in Luang Prabang and Ngeubhinh Mouxeu (e.g. White et al., 2008; 2009; Zeitoun et al., 2012). But, the profusion of lithic implements and the depth of stratigraphy allow us to characterize the assemblage with specific tools and three kinds of knapping processes. We have also demonstrated a stone-tool evolution during the Late Pleistocene-Early Holocene transition is linked with ecological and environmental changes. The classical Hoabinhian techno-complex of Tam Hang with some particularity such as half-sumatralith and hemi-pebbles also identified on Thaï, Cambodian archaeological sites and the Chuandong site in Guizhou Province in China (e.g. Forestier, 2005) indicates the geographical location of the site at the crossroad between Vietnam, Thailand and southern China.

\section{Acknowledgements}

This study was done in the archaeological project "Pa Hang site in Laos, the first modern human History in Southeast Asia" directed by Anne-Marie Bacon and F. Demeter since 2003. It has been supported by the Leakey Foundation, the French Ministry of Foreign Affair, the Ministry of Culture and Information of LAO PDR and the University of Illinois at Urbana-Champaign, USA, the UPR2147 (CNRS), the UMR7206 (MNHN, Paris). The authors would like to thank Bernard Berthier and his team from the Laboratory of Carbon 14 Measurement (LMC14-UMS2572) and Nathalie Gandolfo from the Laboratory of the C2RMF for the sample preparation, the graphitization of the gas samples and the ${ }^{14} \mathrm{C}$ measurements.

\section{References}

Arambourg, C., \& Fromaget, J. (1938). Le gisement quaternaire de Tam Nang (Chaîne Annamitique septentrionale). Sa stratigraphie et ses faunes. Comptes Rendus de l'Académie des Sciences, 203, 793-795.

Aung, Th. (1969). The "Neolithic" Culture of the Padah-Lin Caves. Journal of Burma Research Society, 52, 9-23.

Bacon, A., Demeter, F., Duringer, Ph., Patole-Edoumba, E., Sayavongkhamdy, Th, Coupey, A. M., \& Shackelford, L. (2012). Les sites de Tam Hang, Nam Lot et Tam Pà Ling au nord du Laos: Des gisements à vertébrés du pléistocène aux origines des hommes modernes. Paris: CNRS éditions.

Bacon, A.-M., Demeter, F., Tougard, C., De Vos, J., Sayavongkhamdy, T., Antoine, P.-O., Bouasisengpaseuth, B., \& Sichanthongtip, P. (2008). Redécouverte d'une faune pléistocène dans les remplissages karstiques de Tam Hang au Laos: premiers résultats. Comptes Rendus Palevol, 7, 277-288. http://dx.doi.org/10.1016/j.crpv.2008.03.009

Bacon, A.-M., Duringer, P., Antoine, P-O., Demeter, F., Shackelford, L., Sayavongkhamdy, T., Sichanthongtip, P., Khamdalavong, P., Nokhamaomphu, S., Sysuphanh, V., Patole-Edoumba, E., Chabaux, F., \& Pelt, E. (2011). The Middle Pleistocene Mammalian Fauna from Tam Hang Karstic Deposit, Northern Laos: New Data and Evolutionary Hypothesis. Quaternary International, 245, 315-332. http://dx.doi.org/10.1016/j.quaint.2010.11.024

Bellwood, P. (1993). Cultural and Biological Differentiation in Peninsular Malaysia: The Last 10,000 Years. Asian Perspectives, 32, 37-60.

Bellwood, P. (1997). Prehistory of Indo-Malaysian Archipelago. Honolulu: University of Hawai Press.

Binh, N. (1991). Back to the Periodization of Hoabinhian in Vietnam. Récentes recherches en archéologie en Thaïlande. Bangkok: Silpakorn University.

Boëda, E. (1997). Technogénèse des systèmes de production lithique au Paléolithique inférieur et moyen en Europe occidentale et au Proche-Orient (Vol. 2). Paris : Université de Paris X-Nanterre.

Boëda, E. (2001). Détermination des unités techno-fonctionnelles de pièces bifaciales provenant de la couche acheuléenne C'3 base du site de Barbas. In D. Cliquet (Ed.), Les industries à outils bifaciaux du Paléolithique moyen d'Europe occidentale (pp. 51-75). Liège: ERAUL.

Boriskovsky, P. (1969). Vietnam in Primeval Times. Sovietic Anthropological Archaeology, 8, 214-257. http://dx.doi.org/10.2753/AAE1061-19590803214

Bourguignon, L. (1997). Le Moustérien de type Quina: Nouvelle définition d'une entité technique. PhD Thesis, Nanterre: Université Paris X.

Bowdler, S. (2008). Hoabinhian and Non-Hoabinhian. In J. P. Pautreau, A. S. Coupey, V. Zeitoun, \& E. Rambault (Eds.), From Homo Erectus to the Living Traditions (pp. 59-66). Chiang Mai: Siam Ratana Ltd. Part. 
Colani, M. (1929a). Quelques paléolithes hoabinhiens typiques de l'abri-sous-roche de Lang Kay. Bulletin de l'École Francaise d'Extrême-Orient, 26, 353-384.

Colani, M. (1929b). Quelques stations hoabinhiennes (note préliminaire). Bulletin de l'École Française d'Extrême-Orient, 29, 261-272. http://dx.doi.org/10.3406/befeo.1929.3240

Colani, M. (1932). Champs de jarres monolithiques et de pierres funéraires du Tran-Ninh (Haut Laos). In Congrès des préhistoriens d'Extrême-Orient (pp. 103-128). Hanoi: Imprimeried'Extrême-Orient.

Colani, M. (1935). Mégalithes du Haut-Laos (Hua Pan, Tran Ninh). Paris: École Française d'Extrême-Orient.

Cook, C. G., \& Jones R. T. (2012). Palaeoclimate Dynamics in Continental Southeast Asia over the Last 30,000 Cal yrs BP. Palaeogeography, Palaeoclimatology, Palaeoecology, 339-341, 1-11. http://dx.doi.org/10.1016/j.palaeo.2012.03.025

Demeter, F., Sayavongkhamdy, T., Patole-edoumba, E., Coupey, A. S., Bacon, A.-M., De Vos, J., Tougard, C., Bouasisengpaseuth, B., Sichanthongtip, P., \& Duringer, P. (2010). Tam Hang Rockshelter: Preliminary Study of a Prehistoric Site in Northern Laos. Asian Perspectives, 48, 291-308. http://dx.doi.org/10.1353/asi.2009.0000

Demeter, F., Shackelford, L., Bacon, A. M., Duringer, P., Westawa, K., Sayavongkhamd, T., Braga, J., Sichanthongtip, P., Khamdalavong, P., Ponche, J. L., Wang, H., Lundstrom, C., Patole-Edoumba, E., \& Karpoff, A.-M. (2012). Anatomically Modern Human in Southeast Asia (Laos) by $46 \mathrm{ka}$. Proceedings of the National Academy of Sciences of the United States of America, 109, 14375-14380. http://dx.doi.org/10.1073/pnas.1208104109

Dennell, R. W. (2009). The Palaeolithic Settlement of Asia. New York: Cambridge University Press.

Dunn, F. L. (1964). Excavations at Gua Kecchil, Pahang. Journal of the Malaysian Branch Royal Asiatic Society, 37, 87124.

Forestier, F., Sophady, H., Puaud, S., Celiberti, V., Frère, S., Zeitoun, V., Mourer-Chauviré, C., Mourer, R., Than, H., \& Billault, L. (2015). The Hoabinhian from Laang Spean Cave in Its Stratigraphic, Chronological, Typo-Technological and Environmental Context (Cambodia, Battambang Province). Journal of Archaeological Science, 3, 194-206. http://dx.doi.org/10.1016/j.jasrep.2015.06.008

Forestier, H. (2005). Le site de Tögi Ndrawa, île de Nias, Sumatra nord: Les premières traces d'une occupation hoabinhienne en grotte en Indonésie. Comptes Rendus Palevol, 4, 727-733. http://dx.doi.org/10.1016/j.crpv.2005.08.004

Forestier, H. (2010). Hoabinhian: Flake Stone in Southeast Asia, Mainland to Archipelago. Journal of the Korean Palaeolithic Society, 22, 67-77.

Forestier, H., Zeitoun, V., Winayalai, C., \& Métais, C. (2013). The Open-Air Site of Huai Hin (North-Western Thailand): Chronological Perspectives for the Hoabinhian. Comptes Rendus Palevol, 12, 45-55. http://dx.doi.org/10.1016/j.crpv.2012.09.003

Fromaget, J. (1934). Observations et réflexions sur la géologie stratigraphique et structurale de l'Indochine. Bulletin du Service géologique d'Indochine, 4, 101-164.

Fromaget, J. (1936). Sur la stratigraphie des formations récentes de la Chaîne annamitique septentrionale et sur l'existence de l'homme dans le Quaternaire inférieur de cette partie de l'Indochine. Compte Rendu de L'Académie des Sciences de Paris, 16, $738-741$.

Fromaget, J. (1937a). Études géologiques sur le Nord-Ouest du Tonkin et le Nord du Haut Laos-première partie. Bulletin du Service géologique d'Indochine, 23, 101-164.

Fromaget, J. (1937b). Aperçu sur la stratigraphie et l'anthropologie préhistorique des formations récentes dans la Chaîne annamitique et le Haut-Laos. In Compte rendu de la douzième session du Congrès préhistorique de France (pp. 785-798). Toulouse-Foix: Société Préhistorique de France.

Fromaget, J. (1940a). Les récentes découvertes anthropologiques dans les formations préhistoriques de la Chaîne annamitique. In Proceedings of the Third Congress of Prehistorians of the Far East (pp. 51-59). Singapore: F.N. Chasen and M.W.F. Tweedie.

Fromaget, J. (1940b). La stratigraphie des dépôts préhistoriques de Tam Hang (Chaîne annamitique septentrionale) et ses difficultés. In Proceedings of the Third Congress of Prehistorians of the Far East (pp. 60-70). Singapore: F.N. Chasen and M.W.F. Tweedie.

Fromaget, J. (1941). L'Indochine française, sa structure, ses roches, ses mines et leurs relations possibles avec la tectonique. Bulletin du Service géologique d'Indochine, 26, 1-140.

Fromaget, J. (1952). Études géologiques sur le Nord-Ouest du Tonkin et le Nord du Haut-Laos-première partie. Bulletin du Service géologique d'Indochine, 19, 1-198.

Fromaget, J., \& Saurin, E. (1936). Note préliminaire sur les formations cénozoïques et plus récentes de la Chaîne annamitique septentrionale du haut Laos. Stratigraphie, préhistoire, anthropologie. Bulletin du Service géologique d'Indochine, 22, $7-48$. 
Gaillard, C., Singh, M., \& Malasse, A. D. (2011). Late Pleistocene to Early Holocene Lithic Industries in the Southern Fringes of the Himalaya. Quaternary International, 229, 112-122.

http://dx.doi.org/10.1016/j.quaint.2010.06.023

Glover, I. C. (1977). The Hoabinhian: Hunter-Gatherers or Early Agriculturalists in South-East Asia? In J. V. S. Megaw (Ed.), Hunters, Pastoralists and Early Agriculturalists in South Asia (pp.145-166). Leicester: Leicester University Press.

Gorman, C. (1971). The Hoabinhian and After: Subsistence Patterns in Southeast Asia during the Late Pleistocene and Early Recent Periods. World Archaeology, 2, 300-320. http://dx.doi.org/10.1080/00438243.1971.9979482

Gorman, C. (1972) Excavations at Spirit Cave, North Thailand: Some Interim Interpretations. Asian Perspectives, 13, 79107.

Gourou, P. (1948). La civilisation du végétal. Indonesie, 1, 385-396.

Hayden, B. (1977). Sticks and Stones and Ground Axes: The Upper Palaeolithic in Southeast Asia. In J. Alen, J. Golson, \& R. Jones (Eds.), Sunda and Sahul (pp. 73-109). New York: Academic Press.

Hazarika, M. (2012). Lithic Industries with Palaeolithic Elements in Northeast India. Quaternary International, 269 , 48-58. http://dx.doi.org/10.1016/i.quaint.2011.10.006

Hazarika, M. (2013). Prehistoric Cultural Affinities between Southeast Asia, East Asia and Northeast India: An Exploration. In Unearthing Southeast Asia's Past (pp. 16-25). Singapore: National University.

Higham, C. (2014). Early Mainland in Southeast Asia: From First Humans to Angkor. Bangkok: River Books Press Dist A C.

Higham, C., \& Thosarat, R. (2004). The Excavation of Khok Phanom Di: A Prehistoric Site in Central Thailand (Vol. VII). London: The Society of Antiquaries of London.

Hoang, X. C. (1989). Hoa Binh Culture in Vietnam. Hanoi: Manuscript.

Hutterer, K. L. (1976). An Evolutionary Approach to Southeast Asian Cultural Sequence. Current Anthropology, 17, 221242. http://dx.doi.org/10.1086/201711

Hutterer, K. L. (1977). Reinterpreting the Southeast Asian Palaeolithic. In J. Allen, J. Golson, \& R. Jones (Eds.), Sunda and Sahul (pp. 31-72). New York: Academic Press.

Lepot, M. (1993). Approche techno-fonctionnelle de l'outillage lithique moustérien: Essai de classification des parties actives en termes d'efficacité technique. Application à la couche M2e sagittale de Grand Abri de la Ferrassie. Mémoire de maîtrise, Nanterre: Université Paris X.

Mansuy, H. (1920). Contributions à l'étude de l'Indochine. I. L'industrie de la pierre et du bronze dans la région de Luang Prabang (Haut-Laos). Hanoï: Bulletin du Service géologique d'Indochine 7.

Marwick, B. (2008). What Attributes Are Important for the Measurement of Assemblage Reduction Intensity? Results from an Experimental Stone Artifact Assemblage with Relevance to the Hoabinhian of Mainland Southeast Asia. Journal of Archaeological Science, 35, 1189-1200. http://dx.doi.org/10.1016/j.jas.2007.08.007

Marwick, B. (2013). Multiple Optima in Hoabinhian Flaked Stone Artifact Palaeoeconomics and Palaeoecology at Two Archaeological Sites in Northwest Thailand. Journal of Anthropological Archaeology, 32, 553-564. http://dx.doi.org/10.1016/i.jaa.2013.08.004

Marwick, B., \& Gagan M. K. (2011). Late Pleistocene Monsoon Variability in Northwest Thailand: An Oxygen Isotope Sequence from the Bivalve Margaritanopsis laosensis Excavated in Mae Hong Son Province. Quaternary Scientific Review, 30, 3088-3098. http://dx.doi.org/10.1016/j.quascirev.2011.07.007

Mattews, J. M. (1966). The Hoabinhian Affinities of Some Australian Assemblages. Archaeology and Physical Anthropology in Oceania, 1, 5-22.

Maxwell, A. L. (2001). Holocene Monsoon Changes Inferred from Lake Sediment Pollen and Carbonate Records. Northeastern Cambodia. Quaternary Research, 56, 390-400.

Maxwell, A. L. (2004). Fire Regime in North-Eastern Cambodian Monsoonal Forests, with a 9300-Year Sediment Charcoal Record. Journal of Biogeography, 31, 225-239. http://dx.doi.org/10.1046/j.0305-0270.2003.01015.x

Moser, J. (2001). Hoabinhian, Geographie und Chronologie eines steinzeitlichen Technocomplexes in Südostasien. Köln: Lindensoft.

Moser, J. (2012). The Hoabinhian Definition - In the Past and Today: A Short Historical Review of Defining the Hoabinhian. In M. L. Tjoa-Bonatz, A. Reinecke, \& D. Bonatz (Eds.), Crossing Borders: Selected Papers from the 13th International Conference of the European Association of Southeast Asian Archaeologists, Volume 1 (pp. 3-25). Singapore: National University of Singapore. 
Patole-Edoumba, E. (2012). L'industrie lithique de Tam Hang. In A. M. Bacon et al. (eds.), Les sites de Tam Hang, Nam Lot et Tam Pà Ling au nord du Laos: Des gisements à vertébrés du Pléistocène aux origines des hommes modernes (pp. 65100). Paris: CNRS éditions.

Pavie, A. (1898-1919). Mission Pavie en Indochine 1879-1895 (11 Volumes). Paris: Leroux,

Pawlik, A. (2015). Detecting Traits of Modern Behavioural through Microwear Analysis. A Case Study from the Philippines Terminal Pleistocene. In: Y. Kaifu, \& M. Izuho (Eds.), Emergence and Diversity of Modern Human Behaviour in Palaeolithic Asia (pp. 182-200). College Station, TX: Texas A\&M University Press.

Penny, D. (2001). A 40,000 Year Palynological Record from North-East Thailand; Implications for Biogeography and Paleo-Environmental Reconstruction. Palaeogeography, Palaeoclimatology, Palaeoecology, 171, 97-128. http://dx.doi.org/10.1016/S0031-0182(01)00242-5

Penny, D. (2006). The Holocene History and Development of the Tonle Sap, Cambodia. Quaternary Science Reviews, 25, 310-322. http://dx.doi.org/10.1016/j.quascirev.2005.03.012

Pookajorn, S. (1990). Hoabinhian Cave Excavations in Ban Kao District, West Thailand. In E. Glover, \& I. Glover (Eds.), Southeast Asian Archaeology 1986: Proceedings of the First Conference of the Association of Southeast Asian Archaeologists in Western Europe (pp. 11-28). Oxford: BAR.

Pookajorn, S. (1996). Human Activities and Environmental Changes during the Late Pleistocene to Middle Holocene in Southern Thailand and Southeast Asia. In L. G. Straus et al. (Eds.), Humans at the End of the Lee Age (pp. 201-213). New York: Plenum Press. http://dx.doi.org/10.1007/978-1-4613-1145-4_10

Raymaekers, P. (2001). Prospection archéologique de la vallée laotienne du fleuve Mékong. Volume II: The Artefacts. Oxford: Archeopress.

Reed, K. E. (1997). Early Hominid Evolution and Ecological Change through the African Plio-Pleistocene. Journal of Human Evolution, 32, 289-322. http://dx.doi.org/10.1006/jhev.1996.0106

Santoni, M., Pautreau, J. P., \& Prishanchit, S. (1990). Excavations at Obluang, Province of Chiang Mai, Thailand. In I. Glover, \& E. Glover (Eds.), Southeast Asian Archaeology 1986: Proceedings of the First Conference of the Association of Southeast Asian Archaeologists in Western Europe (pp.37-54). London: BAR International Series 561.

Saurin, E. (1935). Station néolithique à Na Mou, Province de Luang Prabang (Haut-Laos) (Indochine française). Proceedings of the Congrès préhistorique de France, Onzième session, Perigueux, Compte-rendu 11, 258-266.

Saurin, E. (1951). Etudes géologiques et préhistoriques. Bulletin de la Société des Etudes indochinoises, 26, 525-539.

Saurin, E. (1966). Le mobilier préhistorique de l'abri-sous-roche de Tam Pong (Haut Laos). Bulletin de la Société des Études d'Indochine, 41, 106-118.

Saurin, E. (1968). Station préhistorique à ciel ouvert dans le massif du Pha Xieng Tong (Laos). Asian and Pacific Archaeology Series, 2, 86-95.

Sayavongkhamdy, T., Bellwood, P., \& Bulbeck, D. (2000). Recent Archaeological Research in Laos. Bulletin of the Indo-Pacific Prehistory Association, 19, 101-110.

Schick, K. D., \& Zhuan, D. (1993). Early Paleolithic of China and Eastern Asia. Evolutionary Anthropology, 2, 22-35. http://dx.doi.org/10.1002/evan.1360020105

Schoocongdej, R. (1996). Forager Mobility Organisation in Seasonal Tropical Environments: A Review from Lang Kamnan Cave, Western Thailand. Ann. Arbor: the University of Michigan.

Sharma, T. C. (1988). Discovery of Hoabinhian Cultural Relics in Northeast India. In N. C. Ghosh, \& S. Chakrabarty (Eds.), Adaptation and Other Essays: Proceedings of the Archaeological Conference (pp. 136-139). Vishwa Bharati, Shantiniketan: Research Publications.

Solheim, W. G. (1970). Prehistoric Archaeology in Eastern Mainland Southeast Asia and the Philippines. Asian Perspectives, 13, 47-58.

Solheim, W. G. (1974). The Hoabinhian and Island Southeast Asia. In R. B. Tantoco (Ed.), Proceedings of the First Regional Seminar on Southeast Asian Prehistory and Archaeology (pp.19-26). Manila: National Museum of the Philippines.

Soni, A. S., Soni, V. S., \& Rekhi, S. S. (2014). New Types of Stone Tools Found in Soanian Regime of the NW Sub-Himalayas of India. Human Biological Review, 3, 60-87.

Sǿrensen, P. (1982). Hoabinhian and Woodworking in Thailand: A Research Paper in Anthropology for MSC. Philadelphia, PA: University of Pennsylvania.

Soriano, S. (2001). Statut fonctionnel de l'outillage bifacial dans les industries du Paléolithique moyen: Propositions méthodologiques. In D. Cliquet (Ed.), Les industries à outils bifaciaux du Paléolithique moyen d'Europe occidentale (pp. 77-83). Liège: ERAUL. 
Viet, N. (2004). Hoabinhian Food Strategy in Viet Nam. In V. Paz (Ed.), Southeast Asian Archaeology, Wilhelm G. Solheim II (pp. 442-462). Quezon City: Festschrift University of the Philippines Press.

West, J., \& Louys, J. (2007). Differentiating Bamboo from Stone Tool Cut Marks in the Zooarchaeological Record, with a Discussion on the Use of Bamboo Knives. Journal of Archaeological Science, 34, 512-518. http://dx.doi.org/10.1016/j.jas.2006.06.007

White, J. C., \& Bouasisengpaseuth, B. (2008). Archaeology of the Middle Mekong: Introduction to the Luang Prabang Exploratory Survey. In Y. Goudineau, \& M. Lorrillard (Eds.), Recherches Nouvelles sur le Laos.École française d'Extrême Orient (pp. 37-52). Paris: E.F.E.O.

White, J. C., \& Gorman, C. (2004). Patterns in “Amorphous” Industries: The Hoabinhian Viewed through a Lithic Reduction Sequence. In V. Paz (Ed.), Southeast Asian Archaeology, Wilhelm G. Solheim II (pp. 411-441). Quezon City: Festschrift University of the Philippines Press.

White, J. C., Lewis, H., Bouasisengpaseuth, B., Marwick, B., \& Arrell, K. (2009). Archaeological Investigations in Northern Laos: New Contributions to Southeast Asian Prehistory. Antiquity, 83, 319.

Yi, S., Lee, J., Kim, S., Yoo, Y., \& Kim, D. (2008). New Data on the Hoabinhian: Investigations at Hang Cho Cave, Northern Vietnam. Bulletin of the Indo-Pacific Prehistory Association, 28, 73-79. http://dx.doi.org/10.7152/bippa.v28i0.12018

Yosef, O. B., Eren, B., Yuan, J., Cohen, J., \& Li, Y. (2012). Were Bamboo Tools Made in Prehistoric Southeast Asia? An Experimental View from South China. Quaternary International, 269, 9-21. http://dx.doi.org/10.1016/j.quaint.2011.03.026

Zeitoun, V., Forestier, H., \& Nakbunlung, S. (2008). Préhistoires au sud du Triangle d'Or. Paris: Éditions IRD.

Zeitoun, V., Forestier, H. H., Pierret, A., Chiemsisouraj, C., Lorvankham, M., Latthagnot, A., Chanthamoungkhoun, T., \& Norkhamsomphou, S. (2012). Multi-Millennial Occupation in Northwestern Laos: Preliminary Results of Excavations at the Ngeubhinh Mouxeu Rock-Shelter. Comptes Rendus Palevol, 11, 305-313. http://dx.doi.org/10.1016/j.crpv.2011.11.001 